\title{
Identification of Salmonella enterica Genes with a Role in Persistence on Lettuce Leaves During Cold Storage by Recombinase-Based In Vivo Expression Technology
}

\author{
Y. Kroupitski, M. T. Brandl, R. Pinto, E. Belausov, D. Tamir-Ariel, S. Burdman, and S. Sela (Saldinger)
}

First, third, and seventh authors: Microbial Food-Safety Research Unit, Department of Food Quality \& Safety, Institute for Postharvest and Food Sciences, and first author: Department of Biochemistry and Food Science, Robert H. Smith Faculty of Agriculture, Food and Environment, The Hebrew University, Rehovot, Israel; second author: Produce Safety and Microbiology Research Unit, United States Department of Agriculture-Agriculture Research Service, Albany, CA; fourth author: Confocal Microscopy Unit, Agricultural Research Organization (ARO), The Volcani Center, Bet Dagan, Israel; and fifth and sixth authors: Department of Plant Pathology \& Microbiology, The Robert H. Smith Faculty of Agriculture, Food and Environment, The Hebrew University of Jerusalem, Rehovot, Israel.

Accepted for publication 7 January 2013.

\begin{abstract}
Kroupitski, Y., Brandl, M. T., Pinto, R., Belausov, E., Tamir-Ariel, D., Burdman, S., and Sela (Saldinger), S. 2013. Identification of Salmonella enterica genes with a role in persistence on lettuce leaves during cold storage by recombinase-based in vivo expression technology. Phytopathology 103:362-372.

Recurrent outbreaks of enteric illness linked to lettuce and a lack of efficacious strategies to decontaminate produce underscores the need for a better understanding of the molecular interactions of foodborne pathogens with plants. This study aimed at identifying Salmonella enterica genes involved in the persistence of this organism on postharvest lettuce during cold storage using recombinase-based in vivo expression technology (RIVET). In total, 37 potentially induced loci were identified in four distinct screenings. Knockout mutations in eight

upregulated genes revealed that four of them have a role in persistence of the pathogen in this system. These genes included stfC, bcsA, misL, and $y i d R$, encoding a fimbrial outer membrane usher, a cellulose synthase catalytic subunit, an adhesin of the autotransporter family expressed from the Salmonella pathogenicity island-3, and a putative ATP/GTP-binding protein, respectively. $b c s A$, misL, and yidR but not stfC mutants were impaired also in attachment and biofilm formation, suggesting that these functions are required for survival of $S$. enterica on post-harvest lettuce. This is the first report that MisL, which has a role in Salmonella binding to fibronectin in animal hosts, is involved also in adhesion to plant tissue. Hence, our study uncovered a new plant attachment factor in Salmonella and demonstrates that RIVET is an effective approach for investigating human pathogen-plant interactions in a post-harvest leafy vegetable.
\end{abstract}

Lettuce contamination with Salmonella has been linked to multiple" outbreaks of salmonellosis $(14,23,28,30,36,38,57,59)$ and resulted in several recalls by the U.S. produce industry in the last 2 years (http://www.recalls.gov/food.html). Since the emergence of outbreaks of human enteric illness associated with contamination of fruit and vegetables (41), the persistence of human pathogens on produce has been the focus of many studies (7). However our knowledge of the molecular determinants that underlie the behavior of Salmonella on plants is greatly lacking.

Salmonella enterica is an environmentally persistent pathogen. Islam et al. (31) have reported survival of $\leq 63$ days on lettuce in the field. In the post-harvest environment, Salmonella Typhimurium multiplied on loose and head lettuce stored at $15^{\circ} \mathrm{C}$ and survived for 15 days at $4^{\circ} \mathrm{C}$ without substantial population change (61). Others reported that Salmonella Typhimurium populations decreased on shredded iceberg lettuce stored at $4{ }^{\circ} \mathrm{C}$ for 14 days. However, the population size of this organism increased 1,000fold when the lettuce was stored at $22^{\circ} \mathrm{C}$ for 3 days (12). We previously documented the survival of Salmonella Typhimurium on lettuce leaves for 9 days at cold temperature, with preferential

Corresponding author: S. Sela (Saldinger);

E-mail address: shlomos@volcani.agri.gov.il

* The $\boldsymbol{e}$-Xtra logo stands for "electronic extra" and indicates that the online version contains one supplemental figure. Figure 3 appears in color online.

http://dx.doi.org/10.1094/PHYTO-10-12-0254-FI

(C) 2013 The American Phytopathological Society attachment to injured relative to intact lettuce leaf tissue (34). We also reported that the pathogen is capable of penetrating the epidermis of lettuce leaves through stomata in a process that involves flagellar motility and chemotaxis (33), and that this phenomenon occurs also in a number of other leafy vegetables (24). Thus, the prolonged survival of $S$. enterica on lettuce leaves at cold temperatures, a standard condition used for lettuce storage throughout the food chain, and the ability of this organism to multiply on leaves during periods of warm temperature $(8,9)$ pose a serious public health challenge. The lack of an efficacious treatment to decontaminate produce (22) necessitates the development of alternative approaches, such as interference with bacterial persistence on the plant. To this aim, a better understanding of the basic aspects of foodborne pathogen-plant interactions is necessary.

Recombinase in vivo expression technology (RIVET) was originally developed for the identification of genes expressed in human pathogens inside the host $(10,39,42)$. RIVET is a transcriptional reporter system in which a kanamycin $(\mathrm{Km})$-resistance gene (neo) and a sucrose-hydrolyzing ( $a a c B)$ gene cassette flanked by res sites is incorporated into the bacterial genome. The system relies on the induction of a plasmid-based promoterless recombinase $(t n p R)$ from a promoter of interest. Activation of this promoter drives the expression of the recombinase gene, which then catalyzes the excision of the neo-sacB cassette at res sequences from the genome. Consequently, evidence of bacterial promoter activity is inferred from the loss of $\mathrm{Km}$ resistance and the acquisition of resistance to sucrose. In vivo expression technology (IVET) was successfully adapted for the identification 
of plant-inducible genes in plant-associated bacteria $(3,6,43,44$, $52,65,66)$, and in S. enterica (49). Here, we applied RIVET to the identification of $S$. enterica genes that are induced during interaction of this organism with post-harvest lettuce under coldstorage conditions.

\section{MATERIALS AND METHODS}

Bacterial strains, media, and growth conditions. Bacterial strains and plasmids used in this study are listed in Table 1. S. enterica serovar Typhimurium was selected for our RIVET studies as a relevant serovar because it has been implicated in several outbreaks linked to lettuce $(14,28,59)$. Bacteria were grown in Luria-Bertani (LB) broth for 18 to $20 \mathrm{~h}$ at $37^{\circ} \mathrm{C}$ at $150 \mathrm{rpm}$ to obtain stationary phase cultures. When indicated, antibiotics were added to the growth medium at the following concentrations: $\mathrm{Km}$, $50 \mu \mathrm{g} / \mathrm{ml}$; chloramphenicol $(\mathrm{Cm}), 25 \mu \mathrm{g} / \mathrm{ml}$; nalidixic acid (Nal), $30 \mu \mathrm{g} / \mathrm{ml}$; streptomycin (Sm), $100 \mu \mathrm{g} / \mathrm{ml}$; ampicillin (Amp), 100 $\mu \mathrm{g} / \mathrm{ml}$; and gentamicin $(\mathrm{Gm}), 30 \mu \mathrm{g} / \mathrm{ml}$. Enumeration of bacteria was performed by dilution plating (in triplicate) on LB agar with appropriate antibiotics. The number of CFU was determined after incubation of the plates at $37^{\circ} \mathrm{C}$ for $18 \mathrm{~h}$.

Green fluorescent protein labeling. Green fluorescent protein (GFP) labeling of wild-type (WT) and mutant strains of Salmonella was performed by conjugal transfer of pUC18T-miniTn7T-Gm-gfpmut3 (13) and incorporation of the $g f p$ gene into the chromosomal attB site, as described previously (33).

Generation of a Salmonella reporter strain. Two DNA fragments flanking the $a t t B$ gene were polymerase chain reaction (PCR) amplified from Salmonella Typhimurium strain SL1344 with the att1NotI and att2SalI forward and reverse primer pairs (Supplemental Figure 1) to yield 427- and 732-bp DNA fragments, respectively. The two PCR products were digested with NotI and SalI, respectively, and cloned into the NotI and SalI restriction sites of pRES1 $(50,60)$ in two separate reactions to yield plasmid pRESatt harboring a neo-sacB cassette (resl-neosacB-res 1 ) flanked by the two attB DNA fragments. Plasmid pRESatt was electroporated into strain SL1344 and transformants were selected on LB agar plates containing $\mathrm{Km}, \mathrm{Sm}$, and $\mathrm{Nal}$. Because pRESatt cannot multiply in strains lacking the $\lambda$ pir mutation, only clones that underwent two recombination events at the $a t t B$ site will harbor the cassette following integration into the $a t t B$ chromosomal site. Triple antibiotic-resistant clones were replica-plated onto LB plates supplemented with $12 \%$ sucrose to confirm the presence of the $s a c B$ gene on the chromosome. A $\mathrm{Km}$-resistant clone incapable of growing on LB-sucrose agar was isolated and designated SL1344cas. The presence of the neo-sacB cassette in the Salmonella chromosome was confirmed by PCR analysis with flanking $a t t B$ primers and subsequent sequencing.

Construction of the promoter library. The construction of a RIVET library in S. enterica strain SL1344cas was performed as follows. Chromosomal DNA was partially digested with Sau3AI to yield short fragments $(0.5$ to $3 \mathrm{~kb})$. The DNA fragments were ligated into the BamHI site of plasmid pRIV (60), upstream of the tnpR-uidA transcriptional fusion. Following transformation into Escherichia coli CC118-pird, 40,000 recombinant clones were pooled and recombinant plasmids were transferred from $E$. coli into strain SL1344cas by triparental conjugation. Briefly, the recipient strain SL1344cas, the donor E. coli CC118-pird, and a helper E. coli strain (HB101pRK201) were grown in $5 \mathrm{ml}$ of LB with appropriate antibiotics at $37^{\circ} \mathrm{C}$ overnight. Then, $100 \mu \mathrm{l}$ of each culture was transferred into a fresh tube containing $3 \mathrm{ml}$ of LB without antibiotics and bacteria were grown to mid-log phase. This culture $(1 \mathrm{ml})$ was centrifuged and the pellet resuspended in $1 \mathrm{ml}$ of fresh LB. Mid-log cells $(100 \mu \mathrm{l})$ from each strain in the mating were mixed and $100-\mu l$ portions were spotted onto the center of five fresh LB agar plates. Following overnight incubation at $37^{\circ} \mathrm{C}$, bacteria from each plate were resuspended in $5 \mathrm{ml}$ of LB and spread-plated onto LB agar containing antibiotics (Sm, $\mathrm{Nal}, \mathrm{Cm}$, and $\mathrm{Km}$ ) to select for Salmonella transconjugants that underwent homologous recombination. Constitutive promoters in SL1344cas are likely to induce instantaneous excision of the neo$s a c B$ cassette from the chromosome and, therefore, were excluded from the library following selection on the LB-Nal-Sm-Cm-Km. In all, $\approx 20,000$ Salmonella colonies resistant to $\mathrm{Nal}, \mathrm{Sm}, \mathrm{Cm}$, and $\mathrm{Km}$ were collected and pooled in LB broth. The pooled RIVET library was transferred to $8^{\circ} \mathrm{C}$ for $24 \mathrm{~h}$ and, finally, divided into $1001-\mathrm{ml}$ tubes and stored in LB-glycerol $(40 \%)$ at $-80^{\circ} \mathrm{C}$. Then, 10 -fold serial dilutions were plated onto LB agar with and without $12 \%$ sucrose to determine the titer and the promoter-activity background, respectively. No bacterial colonies grew on LBsucrose, indicating that all constitutively expressed promoters

TABLE 1 . Strains and plasmids used in this study

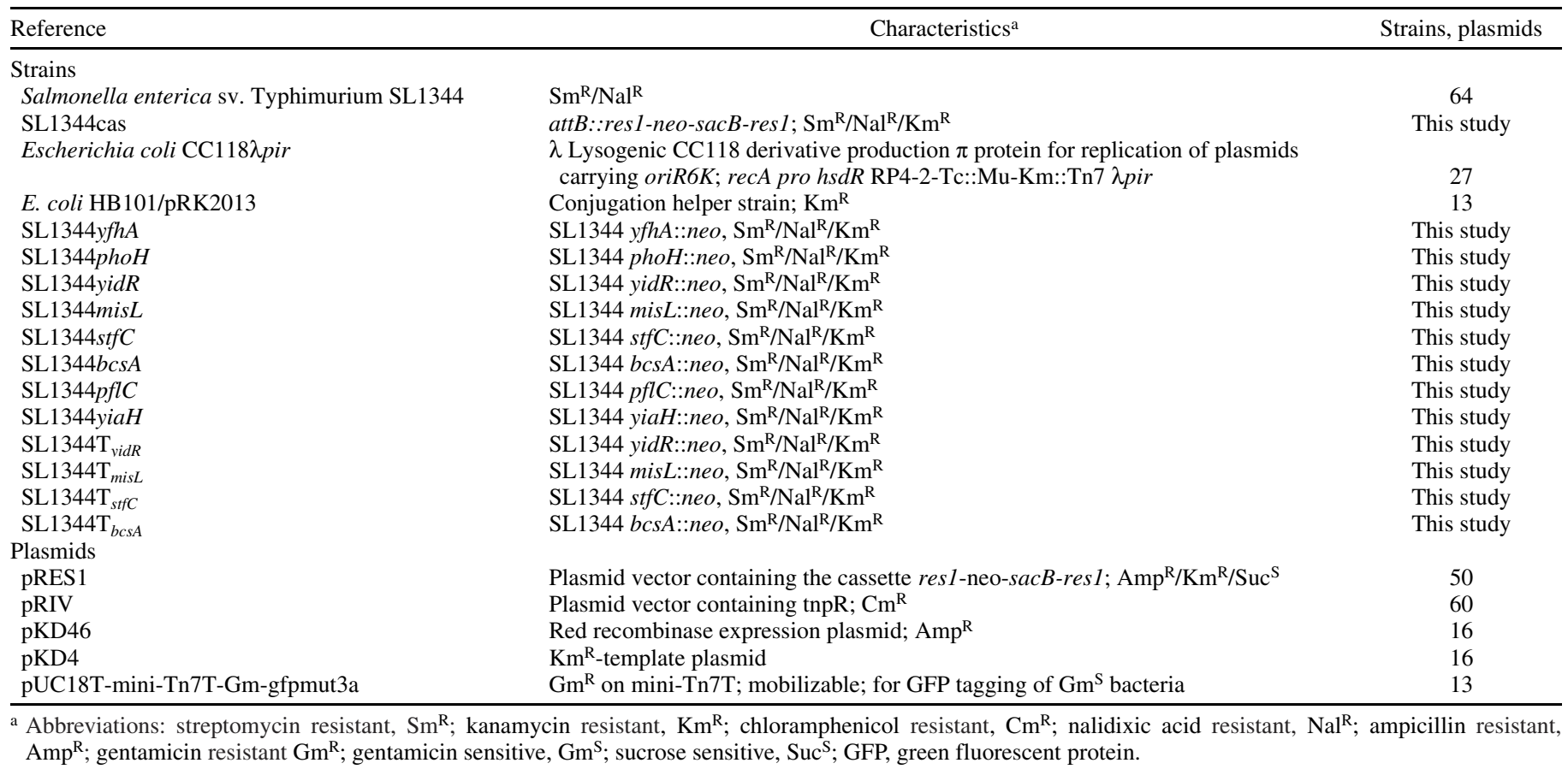


were excluded from the library. The titer of the library was determined by dilution plating onto selective agar plates and assessed to $\mathrm{be} \approx 10^{8} \mathrm{CFU} / \mathrm{ml}$.

Screening for Salmonella promoters induced on lettuce. The pooled RIVET library was thawed, washed twice in sterile distilled water (SDW), and resuspended in SDW at a concentration of $10^{8}$ $\mathrm{CFU} / \mathrm{ml}$. Artificial contamination of intact lettuce leaves and subsequent bacteria recovery for RIVET screening were performed as described below. Following storage at $8^{\circ} \mathrm{C}$ for 7 days, bacteria were recovered from the leaves and plated onto LB agar supplemented with $\mathrm{Nal}, \mathrm{Sm}, \mathrm{Cm}$, and $12 \%$ sucrose to recover only recombinant clones that harbor an induced promoter fusion and, thus, have lost the neo-sacB cassette. To confirm the loss of the cassette, sucrose-resistant clones were replica plated onto LB$\mathrm{Km}$ agar. Sucrose-resistant clones that failed to grow on $\mathrm{Km}$ were selected for further analysis. The screening was repeated on different days with different lettuce in four replicate experiments.

Identification of Salmonella-induced promoters. In order to identify the promoter region of clones harboring an induced transcriptional fusion, arbitrary-primed PCR was carried out as described by O'Toole et al. (51). The arbitrary-primed PCR method uses primers specific to the $5^{\prime}$ end of the $\operatorname{tnp} R$ gene and primers of random sequence that may anneal to chromosomal DNA sequences in close proximity to the plasmid insertion. Two rounds of amplification were used to specifically amplify and enrich DNA fragments flanking the insertion site. The first round of PCR was carried out with a primer unique to the $5^{\prime}$ end of the tnpR gene (RtnpRIVET) and two different arbitrary primers (ARB1 and ARB6). PCR products flanking the tnpR gene were specifically amplified in a second PCR using a primer derived from the tnpR gene (tnpRrev1) and another arbitrary primer (ARB2). The final PCR products were sequenced and the chromosomal DNA region flanking the $t n p R$ gene was identified with the blastn program (1) against $S$. enterica LT2 genomic sequence at the National Center for Biotechnology Information (http:// www.ncbi.nlm.nih.gov/).

Generation of knockout mutants. Site-directed mutagenesis was performed as described by Datsenko and Wanner (16) using primers specific to each of the genes to be analyzed. Briefly, a fragment containing the neo-sacB cassette was amplified from plasmid pKD4 (Table 1) using primers specific to each of the genes. The PCR products were electroporated into strain SL1344 carrying pKD46, which encodes an arabinose-inducible phage $\lambda$ Red recombinase. Homologous recombination between the PCR product and the corresponding chromosomal gene resulted in the insertion of the neo-sacB cassette into the gene of interest. The location of each insertion in the open reading frame and size of deletion is given in Supplemental Figure 1. The absence of the intact gene in the mutants and the authenticity of the nearby DNA sequences were confirmed by PCR and sequence analysis using upstream and downstream chromosomal-derived primers in combination with the respective neo-sacB cassette-derived primer. To confirm the linkage between survival phenotype and a specific mutation, each mutation was further transferred to the WT strain by P22 HT int-105 transduction, as described previously (47). Transductants were isolated on Km plates and the presence of the specific mutation was confirmed by PCR, as described above.

Inoculation of Salmonella onto lettuce leaves, incubation conditions, and bacterial recovery. Whole leaves were sampled from mature harvested heads of Romaine lettuce (Lactuca sativa). Intact (macroscopically undamaged) leaves were used to perform the RIVET screen. For experiments in which intact and injured leaves were used, injuries were made on the leaves with a sterile scalpel by performing cross-wise 4-by-4 superficial incisions (16 incisions in total), each $4 \mathrm{~cm}$ in length, at the mid-rib region of the leaf. Intact and injured leaves were contaminated by spot inoculation with $100 \mu \mathrm{l}$ of $10^{8}$ Salmonella $\mathrm{CFU}$ deposited onto the adaxial surface of the leaf. After inoculation, the leaves were air dried for $1 \mathrm{~h}$ at ambient room temperature and stored at $8^{\circ} \mathrm{C}$ for 7 days in commercial perforated plastic bags made of $25-\mu$ m thick Cryovac polyolefin SM60M (W.R. Grace Ltd., London) to ensure their turgidity and prevent the development of anaerobic conditions. The number of viable Salmonella cells on leaves was determined immediately before cold storage and 7 days later as follows: each lettuce leaf was transferred into $100 \mathrm{ml}$ of SDW in sterile polyethylene bags and homogenized for $1 \mathrm{~min}$ in a stomacher (Interscience BagMixer 400, France) to release attached cells. Samples were serially diluted in SDW and the number of viable Salmonella cells was determined by dilution plating in duplicates on LB agar containing $\mathrm{Nal}$ and $\mathrm{Sm}$ and incubation at $37^{\circ} \mathrm{C}$ for up to $72 \mathrm{~h}$. Population sizes were assessed on three replicate leaves and in three replicate experiments.

Attachment of Salmonella to intact and cut-edges of lettuce leaf. Salmonella attachment to intact and injured leaf surfaces was performed as previously described (34). Briefly, 2-by-2-cm ${ }^{2}$ lettuce leaf pieces were incubated in a Salmonella suspension for $2 \mathrm{~h}$ at $25^{\circ} \mathrm{C}$ and then washed repeatedly to remove unattached bacteria. Washed pieces were further cut peripherally at $3 \mathrm{~mm}$ from the edges to form two subsamples: an internal intact piece and an external piece containing the cut-edges. Three such subsamples of each type of tissue (intact or cut-edges) were combined and bacteria were released from the plant tissue by homogenization using a stomacher. The number of leaf-associated bacteria was determined on both the inner (intact) and the outer (cut) tissues following serial dilutions, as described above. Each experiment was repeated three times with three replicate samples.

Biofilm formation and multicellular behavior. Biofilm formation was assessed in 96-well flat-bottomed polystyrene microtiter plates (Greiner, Germany) at $37^{\circ} \mathrm{C}$, as previously described (34). Briefly, $10 \mu$ of stationary-phase culture $\left(10^{9} \mathrm{CFU} / \mathrm{ml}\right)$ of the tested strain was added to a well containing $90 \mu \mathrm{l}$ of LB without $\mathrm{NaCl}$ (LBNS). The plates were incubated under static conditions at $30^{\circ} \mathrm{C}$ for 3 days, then washed and stained with $0.1 \%$ Crystal violet. Finally, the bound crystal violet was released by acetic acid and the optical density of the eluted crystal violet was measured at $595 \mathrm{~nm}$ using an ELISA Reader (ELx 800 U.V; BioTek Instruments, Inc., Winooski, VT).

Colony morphology was observed on LBNS following a 7-day incubation at $30^{\circ} \mathrm{C}$. The colonies were visualized under a stereomicroscope (STEMI SV8; Zeiss, Germany) and photographed with a digital camera (DXM1200F; Nikon, Tokyo).

Survival of Salmonella at cold temperature. Stationary-phase Salmonella suspensions in $3 \mathrm{ml}$ of SDW $\left(3 \times 10^{7} \mathrm{CFU} / \mathrm{ml}\right)$ were kept at $8^{\circ} \mathrm{C}$ for 7 days. The number of viable Salmonella cells was determined before and after storage. Each experiment was repeated three times with three replicate suspensions.

Dehydration tolerance. Tolerance of Salmonella to dehydration and subsequent storage at cold temperature was assessed by placing $100 \mu \mathrm{l}$ of SDW containing $10^{8} \mathrm{CFU} / \mathrm{ml}$ into a $50-\mathrm{mm}-$ wide polystyrene petri dish (Miniplast, Ein Shemer, Israel). Bacteria were dried for $1 \mathrm{~h}$ at ambient room temperature until no water was visible and the dishes were transferred to $8^{\circ} \mathrm{C}$ (relative humidity of $40 \%$ ) for 7 days. Salmonella CFU were determined before and after dehydration and following 7 days of storage, as described previously (26). Each experiment was repeated three times with three replicate samples.

Confocal microscopy. GFP-labeled bacteria were visualized by confocal laser-scanning microscope (Olympus IX81, Tokyo), using a $\times 10$ objective. Fluorescent bacteria were visualized using an excitation wavelength of $488 \mathrm{~nm}$ and a BA505-525-nm emission filter. A BA660IF emission filter was used to detect chlorophyll autofluorescence. Transmitted light images were obtained using Nomarski differential interference contrast.

Statistical methods. Statistical tests were performed with Instat (version 3.0.6; GraphPad Software, Inc., La Jolla, CA) using an analysis of variance Tukey-Kramer multiple comparisons test. 


\section{RESULTS}

Construction of the RIVET reporter strain. The neo-sacB cassette (res-neo-sacB-res) is a critical element in the RIVET procedure that enables the positive selection of sucrose-resistant clones. Nevertheless, chromosomal insertion of the cassette might inadvertently affect the studied phenotype. In a previous study, the res cassette was stably inserted into the chromosomal attB locus of Mycobacterium smegmatis, which serves as a phage integration site (55). The attB locus in the Salmonella genome serves as a P22 bacteriophage integration site and, therefore, is considered to be a neutral integration site. To ensure that the neo$s a c B$ cassette insertion does not affect the fitness of Salmonella Typhimurium in our lettuce model system, the growth curves of both the WT (SL1344) and SL1344cas strains were compared in LB broth and the survival of these strains on stored lettuce leaves was determined. Both strains had comparable growth kinetics in LB and survival ability on lettuce leaves during 7 days in cold storage (data not shown).

Screening for Salmonella promoters induced on lettuce leaves during cold storage. We have demonstrated previously that Salmonella Typhimurium SL1344 survives during cold storage on lettuce leaf surfaces for prolonged periods of time, with changes in population size of $0.05-$ and $0.01-\log _{10} 3$ and 9 days after inoculation respectively (34). The population size of the pathogen on lettuce at two sampling times during our present study - namely, $1 \mathrm{~h}$ after inoculation and settling of the bacterial cells on the leaf surface and 7 days after storage at $8^{\circ} \mathrm{C}$-is illustrated in Figure 1. Our results show that the population of strain SL1344 declined during cold storage on intact tissue $(P<$ $0.05)$ whereas a small reduction in population size on injured tissue was observed only at an inoculation concentration of $10^{7} \mathrm{CFU} / \mathrm{ml}$. Based on these results, leaf inoculation for the RIVET screening was performed at a concentration of $10^{8} \mathrm{CFU} / \mathrm{ml}$ ( $10^{7}$ cells per $100-\mu l$ inoculation drop).

Screening of the $S$. enterica promoter library was performed on intact lettuce leaves stored for 7 days at $8^{\circ} \mathrm{C}$. Four screenings were performed and resulted in a total of several hundred clones that potentially contained induced promoters. In all, 93 clones were further analyzed and resulted in the identification of 37 different clones harboring a $t n p R$ insertion within a distinct coding sequence. A list of the corresponding genes, which were identified by PCR, and the function that they encode is presented in Table 2. Five genes belong to regulatory systems and cell-cycle regulation proteins, six are homologous to stress response proteins, nine have carbon metabolic functions, five have amino acid metabolic functions, one is involved in protein biosynthesis, seven genes are homologous to transport proteins, and four genes are of unknown function (Table 2).

Survival of selected knockout mutants on lettuce leaf during cold storage. In order to examine the potential involvement of the identified genes in the survival of $S$. enterica on lettuce tissue during cold storage, several genes were selected for further genetic analysis. These included $y f h A, p f l C$, phoH, and yiaH, which were identified multiple times in the four screenings; $y i d R$, which was identified in two screenings; and misL, stfC, and bcsA, which were identified once. In order to examine the involvement of the indicated genes in the survival of $S$. enterica on stored lettuce, isogenic mutants were constructed and tested for the ability to persist on intact and injured leaf tissue. Because abrasions and cuts are an inherent part of lettuce processing, testing of the mutants also on damaged tissue would allow us to determine whether the function of the genes pertained to persistence in a given niche in our lettuce model system. Whereas the viability of the WT strain on intact tissue was only slightly reduced throughout cold storage (Fig. 1), four of the eight mutants (stfC, bcsA, yidR, and misL) were considerably impaired in persistence on intact but not on injured lettuce following 7 days in cold storage $(P \leq 0.05)$ (Fig.
$2 \mathrm{~A}$ and $\mathrm{B})$. On the other hand, the stfC mutant had significantly greater population sizes than the WT strain on injured lettuce after 7 days $(P<0.05)$. To confirm that the phenotype of the above mutants on intact leaf tissue was linked to the presence of the specific knockout mutations, each of the four mutations (in $s t f C$, bcsA, yidR, and misL) were transferred back to the WT strain by transduction. All of the transductants were also impaired in persistence during storage, providing further evidence that these genes have a role in the survival of $S$. enterica on lettuce during cold storage (Fig. 2C).

Attachment and biofilm formation. The survival assay on lettuce did not include a washing step following inoculation (see Material and Methods). Thus, the results of the survival experiments did not allow for inference about the role of the RIVETidentified genes in the attachment of $S$. enterica to the lettuce tissue. To determine whether the lower persistence of the mutants on lettuce is correlated with their ability to adhere to the leaf tissue, we compared the attachment of the WT and mutant strains on both intact and cut leaf tissue. With the exception of the stfC mutant, all three mutants with decreased survival on lettuce had significantly lower attachment to both intact and injured leaf tissue compared with the WT $(P<0.05)$ (Fig. 3A and B).

Because $y i d R$ encodes a hypothetical protein never associated previously with altered behavior of Salmonella on plants, the attachment pattern of the $g f p$-labeled WT and the $g f p$-labeled $y i d R$ mutant to intact and injured tissue was observed under the confocal microscope. Images in Figure $3 \mathrm{~B}$ reveal clearly that the yidR mutant attached to both the cut edge and intact surface of lettuce leaves at densities considerably lower that those of the WT strain.

In a previous study, we demonstrated that $S$. enterica strains that were capable of forming extensive biofilms on polystyrene plates also attached to lettuce leaves better than poor biofilm formers (34). Consequently, we tested the ability of the mutants that showed decreased attachment to lettuce to form biofilms in vitro. All three mutants ( $b c s A, y i d R$, and $m i s L)$ also were impaired in the ability to form biofilms in 96-well polystyrene plates (Fig.

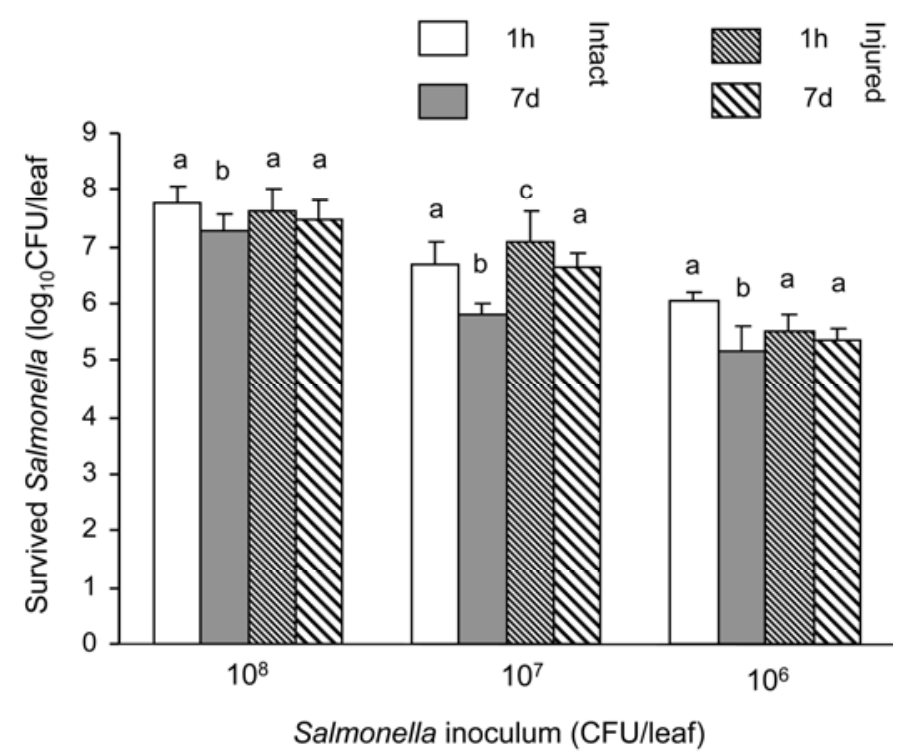

Fig. 1. Survival of Salmonella enterica on intact and injured lettuce leaf during cold storage. Salmonella cells were deposited at various inoculum concentrations onto lettuce leaves by drop inoculation, air dried for $1 \mathrm{~h}$ at ambient room temperature, and stored for 7 days at $8^{\circ} \mathrm{C}$. Salmonella population sizes were determined immediately after drying and before cold storage $(1 \mathrm{~h})$ and following 7 days of cold storage $(7 \mathrm{~d})$. Data represent the means and standard deviation of three replicate samples in three independent experiments. Different letters indicate significant differences $(P<0.05)$ according to analysis of variance Tukey-Kramer multiple comparisons test within each treatment (inoculum level). 
4A). Because biofilm formation is associated with multicellular behavior in S. enterica, a phenotype that is partly reflected by the colony morphology of this organism on LB-no salt agar plates (67), we examined the colony morphology of the above three mutants on the same medium. The WT strain developed wrinkled colonies, whereas the $\mathrm{BcsA}^{-}$mutant formed small and smooth colonies typical of a cellulose-defective mutant (67). The yidR and misL mutants developed wrinkled colonies; however, the central portion of the colonies exhibited a morphology distinct from that of the WT (Fig. 4B).

Bacterial response to low temperature and desiccation. In order to distinguish between genes that are specifically associated with persistence on lettuce during cold storage and those that are merely associated with a cold-stress response, the WT and $s t f C$, $m i s L, b c s A$, and $y i d R$ mutant strains were exposed to $8^{\circ} \mathrm{C}$ for 7 days in SDW without lettuce. Under these conditions, all strains persisted equally without any significant change in cell density $(P<0.05)$, suggesting that low temperature alone was not involved in the induction of the respective genes (Fig. 5A).

Because our experimental set-up for RIVET screening included an initial drying step on the leaves before cold storage, we tested the behavior of the WT and the above mutants in vitro after $1 \mathrm{~h}$ of dehydration followed by a 7-day incubation at $8^{\circ} \mathrm{C}$ in order to determine whether the RIVET-identified genes were induced strictly in response to dehydration or to low temperature. However, none of the mutants impaired in survival on lettuce was defective in survival following dehydration and subsequent cold storage under in vitro conditions (Fig. 5B).

\section{DISCUSSION}

The RIVET system allows for (i) detection of transiently expressed genes, (ii) positive selection of upregulated genes even in the absence of bacterial growth, and (iii) assay of induction of gene expression in as few as one bacterial cell. These features make the RIVET system particularly suitable in our study and economically superior to microarray or RNAseq approaches which, on the other hand, are quantitative and much more comprehensive. Whereas transcriptomic techniques enable the identification of differentially induced genes only at a specific time point, RIVET theoretically allows for identification of all the genes induced during the length of the experiment.

Because sucrose is a major energy-transport molecule in plants, it has been hypothesized recently that $s a c B$ screening may not be a suitable positive selection marker for testing promoter expression in plant-associated bacteria (40), possibly because the endogenous sucrose may confer unintended selection against $s a c B$ containing clones. It must be considered that the concentration of

TABLE 2. List of Salmonella enterica genes identified as upregulated on lettuce at $8^{\circ} \mathrm{C}$ with the recombinase-based in vivo expression technology screen

\begin{tabular}{|c|c|c|c|}
\hline Functional group, gene & Locus tag & Function & Location $^{\mathrm{a}}$ \\
\hline \multicolumn{4}{|l|}{ Regulatory function } \\
\hline$y f h A^{\mathrm{b}}$ & STM2562 & Transcriptional regulator & $2,704,074-2,705,411$ \\
\hline gidA & STM3874 & tRNA uridine 5-carboxymethylaminomethyl modification protein GidA & $4,081,898-4,083,787$ \\
\hline$y i d Z^{\mathrm{b}}$ & STM3848 & DNA-binding transcriptional regulator YidZ & $4,055,233-4,056,192$ \\
\hline$a m p E^{\mathrm{b}}$ & STM0147 & Regulatory protein AmpE & $169,914-170,768$ \\
\hline \multicolumn{4}{|c|}{ Stress response and pathogenicity } \\
\hline$p h o H^{\mathrm{b}}$ & STM1126 & Phosphate starvation-inducible protein & $1,214,245-1,215,169$ \\
\hline $\sin H$ & STM2517 & Intimin-like protein & $2,648,609-2,650,801$ \\
\hline STM3772 & STM3772 & Phosphotransferase system enzyme IIA & $3,971,905-3,972,330$ \\
\hline$f d n G$ & STM1570 & Formate dehydrogenase-N subunit $\alpha$ & $1,650,442-1,653,489$ \\
\hline$p f l C^{\mathrm{b}}$ & STM4115 & Pyruvate formate lyase II activase & $4,331,077-4,331,955$ \\
\hline $\mathrm{yiaH}^{\mathrm{b}}$ & STM3658 & Inner membrane protein & $3,843,367-3,844,362$ \\
\hline aspA & STM4326 & Aspartate ammonia-lyase & $4,570,945-4,572,381$ \\
\hline$y h d H$ & STM3376 & Putative oxidoreductase & $3,547,011-3,547,985$ \\
\hline dapE & STM2483 & Succinyl-diaminopimelate desuccinylase & $2,597,694-2,598,821$ \\
\hline$g l t B^{\mathrm{b}}$ & STM3330 & Glutamate synthase subunit $\alpha$ & $3,494,523-3,498,983$ \\
\hline gltD & STM3331 & Glutamate synthase subunit $\beta$ & $3,498,993-3,500,411$ \\
\hline$y g j U$ & STM3225 & Serine/threonine transporter SstT & $3,393,500-3,394,744$ \\
\hline$p d x J$ & STM2578 & Pyridoxine $5^{\prime}$-phosphate synthase & $2,722,442-2,723,173$ \\
\hline \multicolumn{4}{|l|}{ Protein biosynthesis } \\
\hline$r r s H^{b}$ & STM0249 & $16 \mathrm{~S}$ ribosomal RNA & $289,189-290,732$ \\
\hline \multicolumn{4}{|l|}{ Transporters } \\
\hline$d c u B$ & STM4301 & Anaerobic C4-dicarboxylate transporter & $4,547,107-4,548,447$ \\
\hline pot $H$ & STM0879 & Putrescine $\mathrm{ABC}$ transporter membrane protein & $950,728-95,168$ \\
\hline potA & STM1226 & Putrescine/spermidine $\mathrm{ABC}$ transporter ATPase & $1,312,030-1,313,166$ \\
\hline$y c c S$ & STM1073 & Putative efflux (PET) family transporter & $1,163,692-1,165,845$ \\
\hline$y g d Q$ & STM3006 & Putative integral membrane transport protein & $3,164,258-3,164,971$ \\
\hline
\end{tabular}

${ }^{a}$ Location on Salmonella enterica Typhimurium LT2 chromosome (GenBank accession number NC_003197.1).

${ }^{\mathrm{b}}$ Identified at least twice in different screenings. 
sucrose in iceberg lettuce is $\approx 1 \mathrm{mg} / \mathrm{g}$ fresh weight (33), which is $\approx 100$ times lower than the toxic concentration used for screening the Salmonella RIVET library (10 to $12 \%$ ) in culture medium. It is likely that the actual sucrose level on the surface of intact lettuce leaves, our test environment, is much lower. Using a wholecell biosensor, Miller et al. (48) estimated the concentration of sucrose on the surface of wet bean leaves to be, on average, $20 \mu \mathrm{M}$. Hence, it is unlikely that endogenous sucrose may have affected the RIVET screen in our study system.

In the present study, we employed RIVET as a strategy for the identification of $S$. enterica genes that are upregulated in postharvest lettuce, a potential alternative host in the epidemiological cycle of this pathogen. In the experimental system described in this study, Salmonella sequentially encounter different environmental conditions, starting with a wet environment during inoculation of the pathogen onto lettuce leaves; followed by a dry environment during dehydration of the inoculum on the leaf; and, subsequently, a dry and cold environment throughout storage at $8^{\circ} \mathrm{C}$ for 7 days. This scenario approximated the contamination/ cross-contamination of lettuce tissue with Salmonella cells during processing and cold storage from the production plant to the consumer. Thus, our RIVET strategy aimed at identifying Salmonella genes that may be upregulated throughout this entire process. Because bacterial cells remain metabolically active and may still grow at low temperature, albeit slowly, we intended to identify not only genes induced during the early interaction of the pathogen with lettuce tissue but also those induced during prolonged cold storage in the leaf environment.

The 37 inducible fusions that were located in a coding sequence in our screening pertained to genes encoding a variety of functions. This is concurrent with available data regarding microbial gene expression patterns. Microbial pathogens encounter frequently similar challenges in both animal and plant host environments and, hence, it is not surprising that common functional gene groups are frequently identified in various environments. These usually include genes involved in motility and chemotaxis, nutrient scavenging, central intracellular metabolism, stress response, cell envelope structure, nucleic acid metabolism, and virulence and secretion $(6,32,44,52,60,66)$. IVET is widely utilized to explore mechanisms by which bacteria interact with their environment $(32,53)$. Analysis of gene expression patterns can shed light on the genetics and physiology of microbes in specific ecological niches $(32,53)$. For example, Rediers et al. (53) reported that genes for amino acid uptake are induced predominantly in both plant pathogens and plant-beneficial bacteria upon colonization of the plant host but less in mammalian pathogens. Among the Salmonella-induced genes described in our study, a serine/threonine transporter gene $(y g j U)$ was identified, suggesting that, in the lettuce phyllosphere, Salmonella Typhimurium may activate pathways similar to those in plant-associated bacteria. Indeed, our screen also revealed the induction of genes for the uptake of putrescine and spermidine (pot $H$ and potA). Putrescine and spermidine are two polyamines involved in diverse fundamental cellular processes in plants, including regulation of gene expression, translation, cell proliferation, modulation of cell signaling, and membrane stabilization (58). It has been reported that potE, which codes for a putrescine transporter, was highly upregulated in $S$. enterica sv. Typhimurium in leaves macerated by Dickeyia dadantii (25) and that Pseudomonas fluorescens upregulates a gene involved in putrescine uptake during root colonization (52). Putrescine and spermidine can serve as carbon and nitrogen sources. Their uptake also might interfere with the plant immune response to the benefit of the human pathogen, because putrescine serves as a precursor for spermine, which plays a role as a mediator in defense signaling against plant pathogens (58). Additionally, several of the upregulated genes identified in this study ( $p f l C, k d u D, g l t D, d c u B, y g d Q$, and $d g o T)$ also were upregulated in $S$. enterica during colonization of
D. dadantii soft rot lesions on lettuce, cilantro leaves, or both (25), suggesting that their transcriptional activity is increased in response to environmental cues generally present on leaf tissue.

Using site-specific mutagenesis, we constructed eight mutants of Salmonella Typhimurium that had a deletion in 1 of the 37 genes identified by RIVET. Four of the mutants, defective in StfC, BcsA, YidR, and MisL, had lower population sizes than that of the WT strain on intact leaf tissue 7 days after incubation at $8^{\circ} \mathrm{C}$; WT population sizes remained stable under these conditions. On the other hand, mutations of $b c s A$, yidR, and misL did not affect the ability of the pathogen to survive on injured lettuce tissue, whereas mutation of $s t f C$ as well as that of yiaH improved the survival of this organism in that habitat compared with that of the WT strain. This suggested that StfC, BcsA, YidR, and MisL are involved in the persistence of Salmonella Typhimurium on lettuce leaf surfaces, and indicates that different genes are required for the survival of this pathogen in intact versus dam-

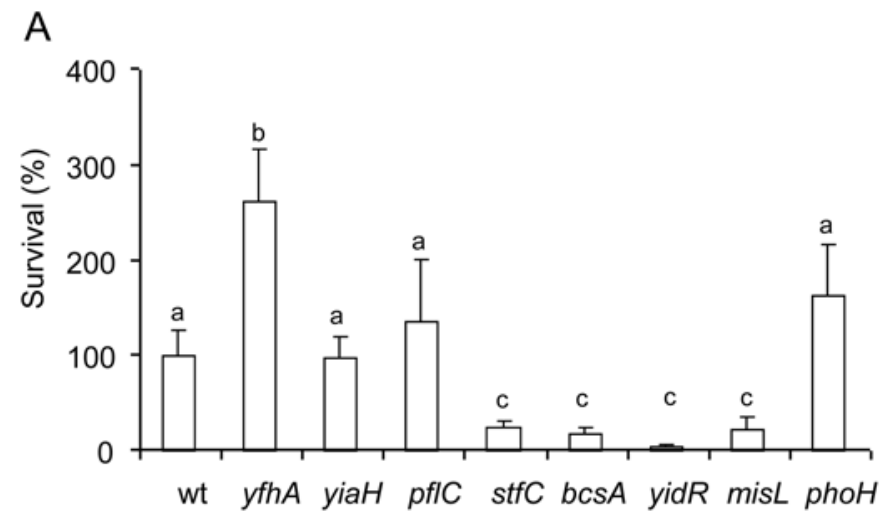

B
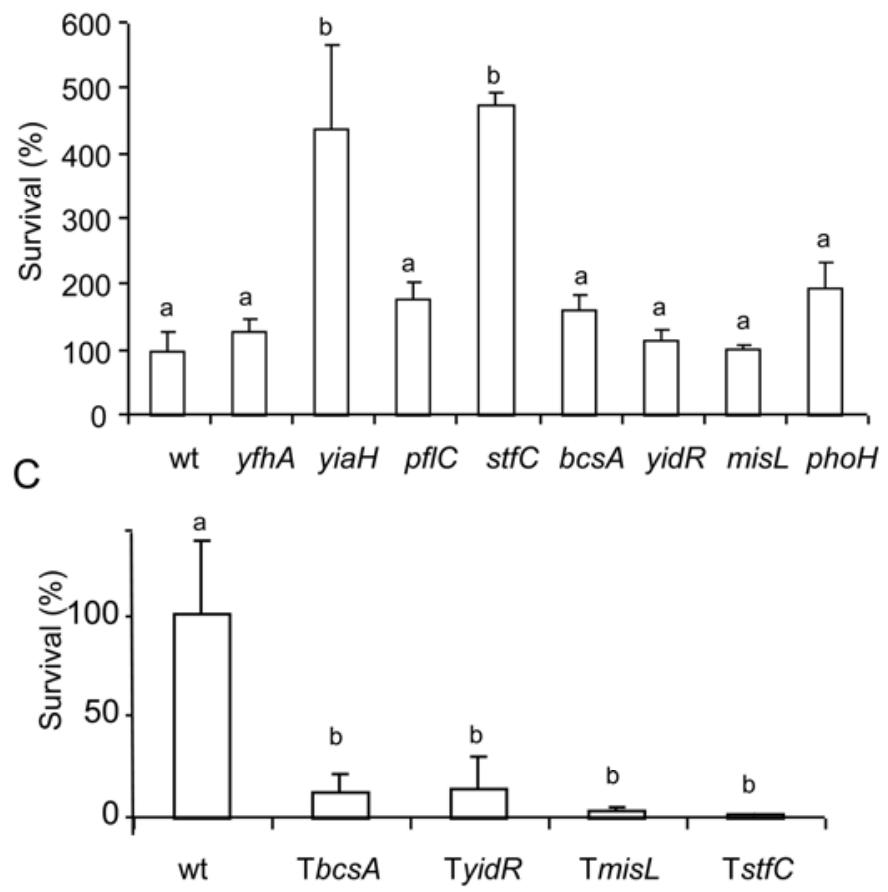

Strains

Fig. 2. Survival of Salmonella enterica mutants compared with that of the wild-type (wt) strain on $\mathbf{A}$, intact and $\mathbf{B}$, injured lettuce leaves following 7 days of cold storage $\left(8^{\circ} \mathrm{C}\right)$. C, Survival of selected transductants on intact leaves. The number of surviving bacteria is presented as percentage of CFU relative to the wt strain $(100 \%)$. Data represent the mean and standard error of survival percentage for three replicate leaves in three independent experiments. Different letters indicate significant differences $(P<0.05)$ according to analysis of variance Tukey-Kramer multiple comparisons test. 
aged leaf tissue. Transduction of the stfC, bcsA, yidR, and misL mutations into the parental background resulted in a behavior similar to that of the original mutants, supporting a role of these genes in persistence of Salmonella Typhimurium on harvested lettuce at cold temperature. misL and $y i d R$ are single-gene operons, whereas stfC is the first gene in a six-gene stf operon and $b c s A$ is the third gene in the six-gene bcs operon. Hence, each of the above mutations inactivated the function of the respective operon.
Bacteria residing on the leaf surface encounter multiple stresses (37). In our model system, $S$. enterica was exposed to desiccation and cold-stress conditions. It is unlikely, however, that $s t f C, b \operatorname{cs} A$, $y i d R$, and misL were induced in response to these stresses per se and, thus, that the mutation caused the observed defect in persistence of the pathogen on lettuce, because the mutant strains showed a tolerance to dehydration and low temperature in vitro similar to that of the WT strain. The possibility remains that other genes identified as inducible in our experimental system that were
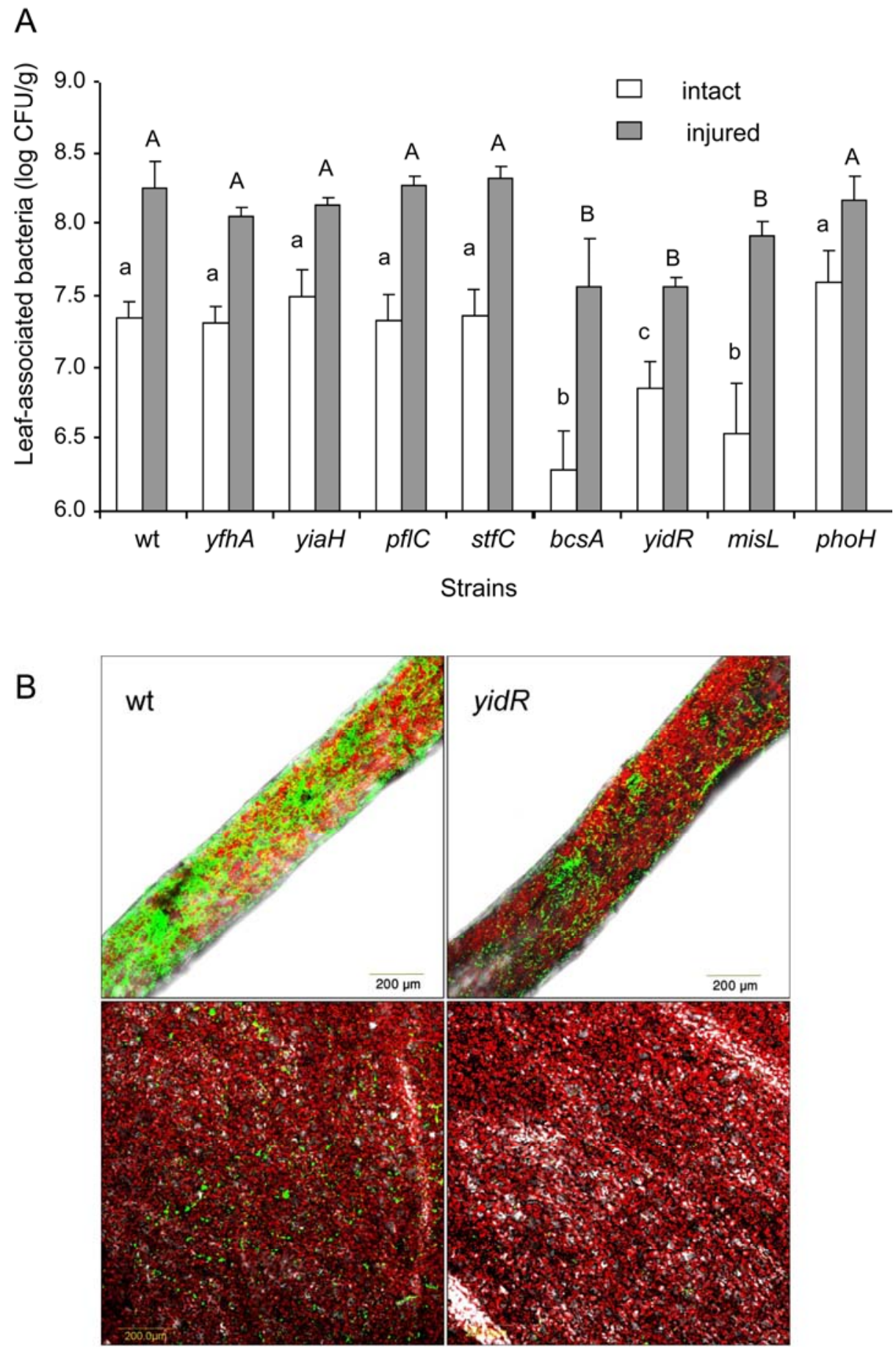

Fig. 3. Attachment of Salmonella enterica wild-type (wt) and mutants to lettuce leaves. A, The number of leaf-associated Salmonella cells on each tissue portion is presented as the average and standard deviation of the log of the number of CFU in three replicate lettuce pieces in three independent experiments. Different letters (lowercase letters: intact tissue group and capital letters: injured tissue group) indicate significant differences $(P<0.05)$ among strains within each treatment (intact and injured leaves) according to analysis of variance Tukey-Kramer multiple comparisons test. B, Confocal microscopy image revealing the attachment of Salmonella green fluorescent protein (GFP)-tagged wt (left panel) and yidR mutant (right panel) cells to the intact and cut leaf tissue. GFP-tagged bacteria (green) are shown associated with the cut edge (side view, upper panel) and on the intact leaf surface (top view, lower panel). Autofluorescence of the chlorophyll is shown in red. Bars $=200 \mu \mathrm{m}$. 
not investigated here have a role in desiccation or cold stress tolerance in S. enterica on lettuce.

Three of the four genes that were targeted for mutagenesis in our study (namely, stfC, bcsA, and misL) have been described previously as having a function in adhesion to and colonization of various surfaces. stfC encodes a fimbrial outer membrane usher involved in the biogenesis of Salmonella Typhimurium fimbriae (Stf). stfC is part of a putative fimbrial operon, stfACDEFG, that was also detected in several other S. enterica serotypes (20). Various Salmonella fimbriae are involved in the adhesion to and invasion of mammalian epithelial cells $(4,19,29)$. Although the population size of the stfC mutant was lower than that of the WT on intact lettuce after incubation at cold temperature, further investigation failed to detect a role of these fimbriae in attachment of the pathogen to lettuce tissue because the stfC mutant and the WT showed similar adhesion in our attachment assay. We have reported previously that Salmonella binds at higher densities to cut than intact lettuce leaf tissue (34), suggesting that different or additional factors may be involved in the interaction of this pathogen with injured plant tissue. Surprisingly, the stfC mutant displayed increased persistence on injured leaf tissue but did not differ from the WT in attachment to this surface, suggesting that Stf may play a role distinct from adhesion in our system. It is also possible that the stfC mutation resulted in an indirect "knock-on effect" on the expression of other surface factors required for bacterial persistence through regulatory cross-talk.

$b c s A$ encodes a cellulose synthase catalytic subunit and is part of the bcsABCD operon present in many bacteria (54). Cellulose
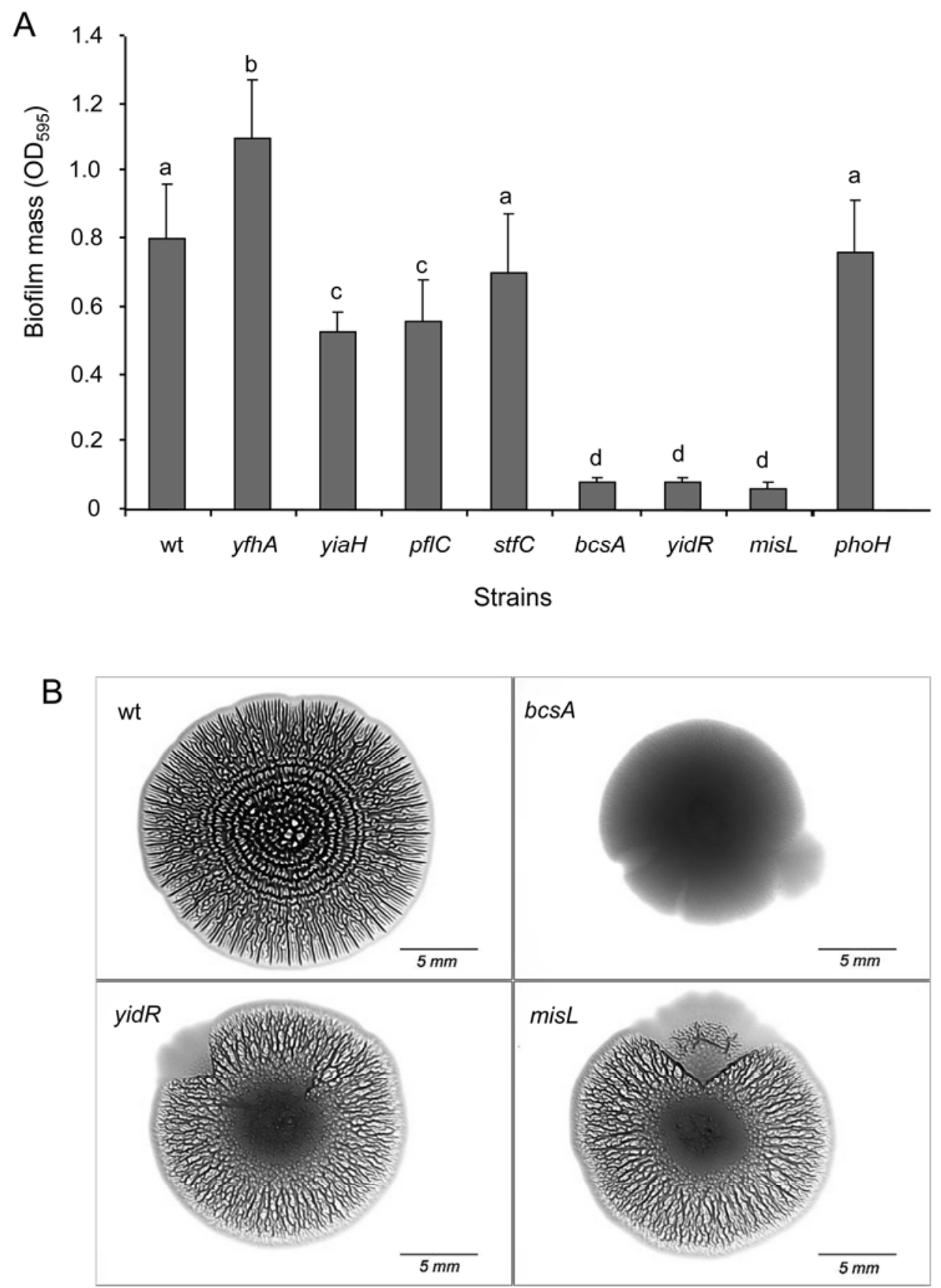

Fig. 4. Biofilm formation and colony morphology of Salmonella enterica wild-type (wt) and mutants. A, Biofilm formation was assessed in 96-well polystyrene plates incubated for 3 days at $25^{\circ} \mathrm{C}$ and measured with the crystal violet method. Data represent the average optical density at $595 \mathrm{~nm}\left(\mathrm{OD}_{595}\right)$ and standard deviation in three replicated wells in three independent experiments. Different letters indicate significant differences $(P<0.05)$ among strains according to analysis of variance Tukey-Kramer multiple comparisons test. B, Multicellular behavior of S. enterica wt and mutant strains as illustrated by colony morphology of each strain following growth at $25^{\circ} \mathrm{C}$ for 7 days on Luria-Bertani without $\mathrm{NaCl}$ agar and observed under the stereomicroscope. Bars $=5 \mathrm{~mm}$. 
is a major component of the extracellular matrix that mediates adhesion, biofilm formation, and the multicellular morphotype in $S$. enterica and E. coli (67) as well as in multiple plant-associated bacteria $(15,63)$. Using an IVET approach, the expression of acetylated cellulose was shown to be important for the ecological success of $P$. fluorescens in the sugar beet rhizosphere and phyllosphere (21). Cellulose was also required for the attachment, colonization, and biofilm formation of Agrobacterium tumefaciens on the tomato root surface (46). In S. enterica and E. coli, cellulose synthesis has been implicated in attachment to various plant species, including alfalfa sprouts $(2,45)$, parsley leaves $(35)$, and tomato fruit (56). Noel et al. (49) also identified bcsA as inducible inside tomato fruit using RIVET and reported reduced competitiveness of an $S$. enterica cellulose-defective mutant in ripe tomato fruit compared with the WT strain. The increased transcription of bcsA in S. enterica on lettuce and the decreased ability of the $b \operatorname{cs} A$ mutant to attach to both intact and injured lettuce tissue point to a role for cellulose in the persistence of Salmonella Typhimurium on cold-stored lettuce. Because cellulose has a known function in Salmonella biofilm formation in vitro, which we confirmed in strain SL1344 in this study, it may also mediate an intimate cell-to-cell contact necessary for the survival of this organism under cold conditions on stored lettuce.

Our results also revealed that MisL was implicated in the interaction of $S$. enterica with lettuce. misL consists of a single gene operon on the Salmonella pathogenicity island 3 (SPI-3) and encodes an adhesin of the autotransporter family (5). This nonfimbrial adhesin is required for intestinal persistence of $S$. enterica in a mouse model of infection and functions as an intestinal colonization factor by binding fibronectin (17). It is noteworthy that misL is not expressed in planktonic LB-grown Salmonella cells and is likely expressed only during infection $(5,62)$. Here, we demonstrate that misL also is expressed in the plant environment and that an intact gene is required for attachment of Salmonella Typhimurium to lettuce and for efficient biofilm
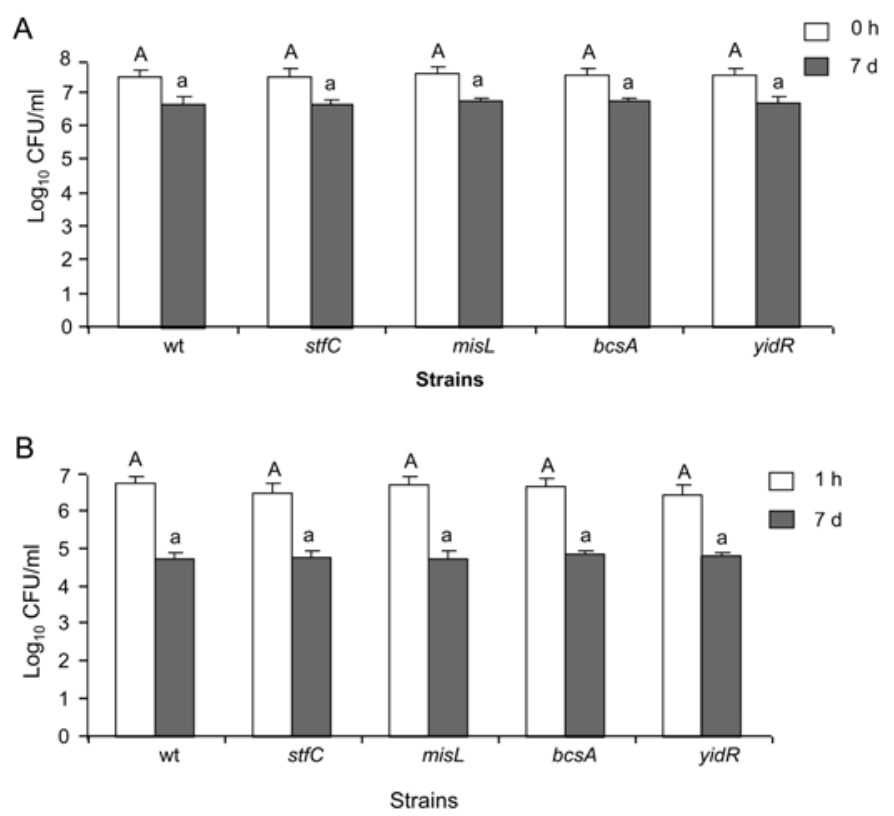

Fig. 5. Survival of Salmonella enterica wild-type (wt) and mutant strains at low temperature and following dehydration. A, S. enterica concentration at $0 \mathrm{~h}$ and 7 days of incubation in sterile distilled water (SDW) at $8^{\circ} \mathrm{C}$. B, Population sizes after $1 \mathrm{~h}$ of dehydration at room temperature $\left(25^{\circ} \mathrm{C}\right)$ and after a subsequent 7 days of storage at $8^{\circ} \mathrm{C}$. Data represent the mean and standard deviation of three replicate samples in three independent experiments. Identical letters (lowercase letters: 0 or $1 \mathrm{~h}$ and capital letters: 7 days) within a treatment (SDW or dehydration) indicate nonsignificant differences of the means according to the analysis of variance Tukey-Kramer multiple comparisons test $(P>0.05)$. formation in vitro. Hence, this adhesin appears to mediate binding of the pathogen to animal and plant tissue and to abiotic surfaces.

In $S$. enterica and E. coli, the YidR protein is regarded as a putative ATP/GTP-binding protein (http://www.xbase.ac.uk). The YidR protein contains two conserved domains: DUF3748 (amino acids 62-179), a prokaryotic and eukaryotic conserved domain of unknown function, and a tolB domain (amino acids 282 to 389) (http://www.ncbi.nlm.nih.gov/protein/16422383). TolB is a periplasmic protein that is part of the Tol-Pal (peptidoglycan-associated lipoprotein) multiprotein complex required for outer-membrane integrity. The complex is associated with Tol-dependent translocation of colicins and single-stranded DNA of certain filamentous bacteriophages into E. coli (11) and is implicated in the pathogenesis of E. coli, Haemophilus ducreyi, S. enterica, and Vibrio cholerae (18). Although we demonstrated here that deletion of yidR inhibited the attachment of S. enterica to lettuce and biofilm formation in vitro, the underlying mechanism responsible for the involvement of this gene in the persistence of the pathogen on lettuce at cold temperature is unclear.

Overall, the behavior of the bcsA, misL, and yidR mutants provides evidence that attachment to the leaf tissue is an important trait for Salmonella Typhimurium survival on the leaf surface. The observation that a defect in attachment of a given mutant to lettuce tissue correlates with impaired ability to form biofilms in vitro is consistent with our previous finding that Salmonella strains that are poor biofilm producers also bind to lettuce leaf tissue at low densities (34). It is likely that other genes that we identified by RIVET in our system but did not investigate in this study have a role in other aspects of Salmonella Typhimurium survival in post-harvest lettuce at cold temperature. Elucidation of the function of some of these inducible genes may further shed light on the complex biology of this enteric pathogen on leafy vegetables during processing and storage for human consumption.

\section{ACKNOWLEDGMENTS}

This study was partially supported by The United States-Israel Binational Agricultural Research and Development (BARD) Fund, grant number US-3949-06, awarded to S. Sela (Saldinger) and M. T. Brandl. We thank A. Camilli (Tufts University, Boston) for RIVET plasmids and strains.

\section{LITERATURE CITED}

1. Altschul, S. F., Gish, W., Miller, W., Myers, E. W., and Lipman, D. J. 1990. Basic local alignment search tool. J. Mol. Biol. 215:403-410.

2. Barak, J. D., Jahn, C. E., Gibson, D. L., and Charkowski, A. O. 2007. The role of cellulose and $\mathrm{O}$-antigen capsule in the colonization of plants by Salmonella enterica. Mol. Plant-Microbe Interact. 20:1083-1091.

3. Barr, M., East, A. K., Leonard, M., Mauchline, T. H., and Poole P. S. 2008. In vivo expression technology (IVET) selection of genes of Rhizobium leguminosarum biovar viciae A34 expressed in the rhizosphere. FEMS Microbiol. Lett. 282:219-227.

4. Baumler, A. J., Tsolis, R. M., and Heffron, F. 1997. Fimbrial adhesins of Salmonella typhimurium. Role in bacterial interactions with epithelial cells. Adv. Exp. Med. Biol. 412:149-158.

5. Blanc-Potard, A. B., Solomon, F., Kayser, J., and Groisman, E. A. 1999. The SPI-3 pathogenicity island of Salmonella enterica. J. Bacteriol. 181:998-1004.

6. Boch, J., Joardar, V., Gao, L., Robertson, T. L., Lim, M., and Kunkel, B. N. 2002. Identification of Pseudomonas syringae pv. tomato genes induced during infection of Arabidopsis thaliana. Mol. Microbiol. 44:7388.

7. Brandl, M. T. 2006. Fitness of human enteric pathogens on plants and implications for food safety. Annu. Rev. Phytopathol. 44:367-392.

8. Brandl, M. T., and Amundson, R. 2008. Leaf age as a risk factor in contamination of lettuce with Escherichia coli O157:H7 and Salmonella enterica. Appl. Environ. Microbiol. 74:2298-2306.

9. Brandl, M. T., and Mandrell, R. E. 2002. Fitness of Salmonella enterica serovar Thompson in the cilantro phyllosphere. Appl. Environ. Microbiol. 68:3614-3621 
10. Camilli, A., and Mekalanos, J. 1995. Use of recombinase gene fusions to identify Vibrio cholerae genes induced during infection. Mol. Microbiol. 18:671-683.

11. Cascales, E., Buchanan, S. K., Duche, D., Kleanthous, C., Lloubes, R., Postle, K., Riley, M., Slatin, S., and Cavard, D. 2007. Colicin biology. Microbiol. Mol. Biol. Rev. 71:158-229.

12. Chang, J. M., and Fang, T. J. 2007. Survival of Escherichia coli O157:H7 and Salmonella enterica serovar Typhimurium in iceberg lettuce and the antimicrobial effect of rice vinegar against E. coli O157:H7. Food Microbiol. 24:745-751.

13. Choi, K. H., and Schweizer, H. P. 2006. Mini-Tn7 insertion in bacteria with single attTn7 sites: Example Pseudomonas aeruginosa. Nat. Protocols 1:153-161.

14. Crook, P. D., Aguilera, J. F., Threlfall, E. J., O'Brien, S. J., Sigmundsdottir, G., Wilson, D., Fisher, I. S., Ammon, A., Briem, H., Cowden, J. M., Locking, M. E., Tschape, H., van Pelt, W., Ward, L. R., and Widdowson, M. A. 2003. A European outbreak of Salmonella enterica serotype Typhimurium definitive phage type 204b in 2000. Clin. Microbiol. Infect. 9:839-845.

15. Danhorn., T., and Fuqua, C. 2007. Biofilm formation by plant associated bacteria. Annu. Rev. Microbiol. 61:401-422.

16. Datsenko, K. A., and Wanner, B. L. 2000. One-step inactivation of chromosomal genes in Escherichia coli K-12 using PCR products. Proc. Natl. Acad. Sci. USA 97:6640-6645.

17. Dorsey, C. W., Laarakker, M. C., Humphries, A. D., Weening, E. H., and Baumler, A. J. 2005. Salmonella enterica serotype Typhimurium MisL is an intestinal colonization factor that binds fibronectin. Mol. Microbiol. 57:196-211.

18. Dubuisson, J. F., Vianney, A., Hugouvieux-Cotte-Pattat, N., and Lazzaroni, J. C. 2005. Tol-Pal proteins are critical cell envelope components of Erwinia chrysanthemi affecting cell morphology and virulence. Microbiology 151:3337-3347.

19. Edwards, R. A., Schifferli, D. M., and Maloy, S. R. 2000. A role for Salmonella fimbriae in intraperitoneal infections. Proc. Natl. Acad. Sci. USA 97:1258-1262.

20. Emmerth, M., Goebel, W., Miller, S. I., and Hueck, C. J. 1999. Genomic subtraction identifies Salmonella typhimurium prophages, F-related plasmid sequences, and a novel fimbrial operon, stf, which are absent in Salmonella typhi. J. Bacteriol. 181:5652-5661.

21. Gal, M., Preston, G. M., Massey, R. C., Spiers, A. J., and Rainey, P. B. 2003. Genes encoding a cellulose polymer contribute toward the ecological success of Pseudomonas fluorescens SBW25 on plant surfaces. Mol. Ecol. 12:3109-3121.

22. Gil, M. I., Selma, M. V., Lopez-Galvez, F., and Allende, A. 2009. Freshcut product sanitation and wash water disinfection: Problems and solutions. Int. J. Food Microbiol. 134:37-45.

23. Gillespie, I. 2004. Outbreak of Salmonella Newport infection associated with lettuce in the UK. Eur. Surveill. 8:2562.

24. Golberg, D., Kroupitski, Y., Belausov, E., Pinto, R., and Sela, S. 2011. Salmonella Typhimurium internalization is variable in leafy vegetables and fresh herbs. Int. J. Food Microbiol. 145:250-257.

25. Goudeau, D. M., Parker, C. T., Zhou, Y., Sela, S., Kroupitski, Y., and Brandl, M. T. 2013. The Salmonella transcriptome in lettuce and cilantro soft rot reveals a niche overlap with the animal host intestine. Appl. Environ. Microbiol. 79:250-262.

26. Gruzdev, N., Pinto, R., and Sela, S. 2011. Effect of desiccation on tolerance of Salmonella enterica to multiple stresses. Appl. Environ. Microbiol. 77:1667-1673.

27. Hensel, M., Shea, J. E., Gleeson, C., Jones, M. D., Dalton, E., and Holden, D. W. 1995. Simultaneous identification of bacterial virulence genes by negative selection. Science 269:400-403.

28. Horby, P. W., O'Brien, S. J., Adak, G. K., Graham, C., Hawker, J. I., Hunter, P., Lane, C., Lawson, A. J., Mitchell, R. T., Reacher, M. H., Threlfall, E. J., and Ward, L. R. 2003. A national outbreak of multiresistant Salmonella enterica serovar Typhimurium definitive phage type (DT) 104 associated with consumption of lettuce. Epidemiol. Infect. 130:169-178.

29. Humphries, A. D., Townsend, S. M., Kingsley, R. A., Nicholson, T. L., Tsolis, R. M., and Baumler, A. J. 2001. Role of fimbriae as antigens and intestinal colonization factors of Salmonella serovars. FEMS Microbiol. Lett. 201:121-125

30. Irvine, W. N., Gillespie, I. A., Smyth, F. B., Rooney, P. J., McClenaghan, A., Devine, M. J., and Tohani, V. K. 2009. Investigation of an outbreak of Salmonella enterica serovar Newport infection. Epidemiol. Infect. 137:1449-1456.

31. Islam, M., Morgan, J., Doyle, M. P., Phatak, S. C., Millner, P., and Jiang, X. 2004. Persistence of Salmonella enterica serovar typhimurium on lettuce and parsley and in soils on which they were grown in fields treated with contaminated manure composts or irrigation water. Foodborne Pathog. Dis. 1:27-35.
32. Jackson, R. W., and Giddens, S. R. 2006. Development and application of in vivo expression technology (IVET) for analysing microbial gene expression in complex environments. Infect. Disorders Drug Targets 6:207-240.

33. Kroupitski, Y., Golberg, D., Belausov, E., Pinto, R., Swartzberg, D., Granot, D., and Sela, S. 2009. Internalization of Salmonella enterica in leaves is induced by light and involves chemotaxis and penetration through open stomata. Appl. Environ. Microbiol. 75:6076-6086.

34. Kroupitski, Y., Pinto, R., Brandl, M. T., Belausov, E., and Sela, S. 2009. Interactions of Salmonella enterica with lettuce leaves. J. Appl. Microbiol. 106:1876-1885.

35. Lapidot, A., and Yaron, S. 2009. Transfer of Salmonella enterica serovar Typhimurium from contaminated irrigation water to parsley is dependent on curli and cellulose, the biofilm matrix components. J. Food Prot. 72:618-623.

36. Lienemann, T., Niskanen, T., Guedes, S., Siitonen, A., Kuusi, M., and Rimhanen-Finne, R. 2011. Iceberg lettuce as suggested source of a nationwide outbreak caused by two Salmonella serotypes, Newport and Reading, in Finland in 2008. J. Food Prot. 74:1035-1040.

37. Lindow, S. E., and Brandl, M. T. 2003. Microbiology of the phyllosphere. Appl. Environ. Microbiol. 69:1875-1883.

38. Long, S. M., Adak, G. K., O'Brien, S. J., and Gillespie, I. A. 2002. General outbreaks of infectious intestinal disease linked with salad vegetables and fruit, England and Wales, 1992-2000. Commun. Dis. Public Health 5:101-105.

39. Lowe, A. M., Beattie, D. T., and Deresiewicz, R. L. 1998. Identification of novel staphylococcal virulence genes by in vivo expression technology. Mol. Microbiol. 27:967-976.

40. Lozano, M. J., Salas, M. E., Giusti, M. A., Draghi, W. O., Tejerizo, G. A. T., Martini, M. C., Del Papa, M. F., Pistorio, M., and Lagares, A. 2011. Development of new positive-selection RIVET tools: Detection of induced promoters by the excision-based transcriptional activation of an aacCI $(\mathrm{Gm}(\mathrm{R}))$ - $g f p$ fusion. J. Biotechnol. 155:147-155.

41. Lynch, M. F., Tauxe, R. V., and Hedberg, C. W. 2009. The growing burden of foodborne outbreaks due to contaminated fresh produce: risks and opportunities. Epidemiol. Infect. 137:307-315.

42. Mahan, M. J., Slauch, J. M., and Mekalanos, J. J. 1993. Selection of bacterial virulence genes that are specifically induced in host tissues. Science 259:686-688.

43. Marco, M. L., Legac, J., and Lindow, S. E. 2003. Conditional survival as a selection strategy to identify plant-inducible genes of Pseudomonas syringae. Appl. Environ. Microbiol. 69:5793-5801.

44. Marco, M. L., Legac, J., and Lindow, S. E. 2005. Pseudomonas syringae genes induced during colonization of leaf surfaces. Environ. Microbiol. 7:1379-1391.

45. Matthysse, A. G., Deora, R., Mishra, M., and Torres, A. G. 2008. Polysaccharides cellulose, poly-beta-1,6-n-acetyl-D-glucosamine, and colanic acid are required for optimal binding of Escherichia coli O157:H7 strains to alfalfa sprouts and K-12 strains to plastic but not for binding to epithelial cells. Appl. Environ. Microbiol. 74:2384-2390.

46. Matthysse, A. G., Marry, M., Krall, L., Kaye, M., Ramey, B. E., Fuqua, C., and White, A. R. 2005. The effect of cellulose overproduction on binding and biofilm formation on roots by Agrobacterium tumefaciens. Mol. Plant-Microbe Interact. 18:1002-1010.

47. Miller, J. H. 1972. Experiments in Molecular Genetics. Cold Spring Harbor Laboratory, Cold Spring Harbor, NY.

48. Miller, W. G., Brandl, M. T., Quiñones, B., and Lindow, S. E. 2001 Biological sensor for sucrose availability: relative sensitivities of various reporter genes. Appl. Environ. Microbiol. 67:1308-1317.

49. Noel, J. T., Arrach, N., Alagely, A., McClelland, M., and Teplitski, M. 2010. Specific responses of Salmonella enterica to tomato varieties and fruit ripeness identified by in vivo expression technology. PLoS One 5:e12406.

50. Osorio, C. G., Crawford, J. A., Michalski, J., Martinez-Wilson, H., Kaper, J. B., and Camilli, A. 2005. Second-generation recombination-based in vivo expression technology for large-scale screening for Vibrio cholerae genes induced during infection of the mouse small intestine. Infect. Immun. 73:972-980

51. O'Toole, G. A., Pratt, L. A., Watnick, P. I., Newman, D. K., Weaver, V. B., and Kolter, R. 1999. Genetic approaches to study of biofilms. Methods Enzymol. 310:91-109.

52. Rainey, P. B. 1999. Adaptation of Pseudomonas fluorescens to the plant rhizosphere. Environ. Microbiol. 1:243-257.

53. Rediers, H., Rainey, P. B., Vanderleyden, J., and De Mot, R. 2005 Unraveling the secret lives of bacteria: use of in vivo expression technology and differential fluorescence induction promoter traps as tools for exploring niche-specific gene expression. Microbiol. Mol. Biol. Rev. 69:216-217.

54. Ross, P., Mayer, R., and Benziman, M. 1991. Cellulose biosynthesis and function in bacteria. Microbiol. Rev. 55:35-58. 
55. Saviola, B., Woolwine, S. C., and Bishai, W. R. 2003. Isolation of acidinducible genes of Mycobacterium tuberculosis with the use of recombinase-based in vivo expression technology. Infect. Immun. 71:13791388.

56. Shaw, Robert K., Lasa, Iñigo, García, Begoña M., Pallen, Mark J., Hinton, Jay C. D., Berger, Cedric N., and Frankel, G. 2011. Cellulose mediates attachment of Salmonella enterica Serovar Typhimurium to tomatoes. Environ. Microbiol. Rep. 3:569-573.

57. Stafford, R. J., McCall, B. J., Neill, A. S., Leon, D. S., Dorricott, G. J., Towner, C. D., and Micalizzi, G. R. 2002. A statewide outbreak of Salmonella Bovismorbificans phage type 32 infection in Queensland. Commun. Dis. Intell. 26:568-573.

58. Takahashi, T., and Kakehi, J. 2010. Polyamines: Ubiquitous polycations with unique roles in growth and stress responses. Ann. Bot. 105:1-6.

59. Takkinen, J., Nakari, U. M., Johansson, T., Niskanen, T., Siitonen, A., and Kuusi, M. 2005. A nationwide outbreak of multiresistant Salmonella Typhimurium in Finland due to contaminated lettuce from Spain, May 2005. Eur. Surveill. 10:E050630.

60. Tamir-Ariel, D., Navon, N., and Burdman, S. 2007. Identification of genes in Xanthomonas campestris pv. vesicatoria induced during its interaction with tomato. J. Bacteriol. 189:6359-6371.

61. Tian, J. Q., Bae, Y. M., Choi, N. Y., Kang, D. H., Heu, S., and Lee, S. Y.
2012. Survival and growth of foodborne pathogens in minimally processed vegetables at 4 and $15^{\circ} \mathrm{C}$. J. Food Sci. 77:M48-50.

62. Tukel, C., Akcelik, M., de Jong, M. F., Simsek, O., Tsolis, R. M., and Baumler, A. J. 2007. MarT activates expression of the MisL autotransporter protein of Salmonella enterica serotype Typhimurium. J. Bacteriol. 189:3922-3926.

63. Ude, S., Arnold, D. L., Moon, C. D., Timms-Wilson, T., and Spiers, A. J. 2006. Biofilm formation and cellulose expression among diverse environmental Pseudomonas isolates. Environ. Microbiol. 8:1997-2011.

64. Wray, C., and Sojka, W. J. 1978. Experimental Salmonella typhimurium infection in calves. Res. Vet. Sci. 25:139-143.

65. Yang, S., Perna, N. T., Cooksey, D. A., Okinaka, Y., Lindow, S. E., Ibekwe, A. M., Keen, N. T., and Yang, C. H. 2004. Genome-wide identification of plant-upregulated genes of Erwinia chrysanthemi 3937 using a GFP-based IVET leaf array. Mol. Plant-Microbe Interact. 17:999-1008.

66. Zhao, Y., Blumer, S. E., and Sundin, G. W. 2005. Identification of Erwinia amylovora genes induced during infection of immature pear tissue. J. Bacteriol. 187:8088-8103.

67. Zogaj, X., Nimtz, M., Rohde, M., Bokranz, W., and Romling, U. 2001. The multicellular morphotypes of Salmonella typhimurium and Escherichia coli produce cellulose as the second component of the extracellular matrix. Mol. Microbiol. 39:1452-1463. 